\title{
A method for evaluating antiviral drug susceptibility of Epstein-Barr virus
}

\author{
This article was published in the following Dove Press journal: \\ Virus Adaptation and Treatment \\ 22 January 2010 \\ Number of times this article has been viewed
}

\author{
Charlotte A Romain' \\ Henry H Balfour Jr ${ }^{1,2}$ \\ Heather E Vezina ${ }^{1,3}$ \\ Carol J Holman' \\ 'Department of Laboratory Medicine \\ and Pathology, ${ }^{2}$ Department \\ of Pediatrics, ${ }^{3}$ Department \\ of Experimental and Clinical \\ Pharmacology, University of \\ Minnesota, Minneapolis, MN, USA
}

\begin{abstract}
We developed an in vitro Epstein-Barr virus (EBV) drug susceptibility assay using P3HR1 cells or lymphoblastoid cells from subjects with infectious mononucleosis, which were grown in the presence of various concentrations of acyclovir (ACV), ganciclovir (GCV) or R-9-[4-hydroxy-2-(hydroxymethyl)butyl]guanine (H2G) and 12-O-tetradecanoyl-phorbol-13acetate (TPA). On day 7, total cellular DNA was extracted and EBV DNA was detected using an in-house quantitative real-time polymerase chain reaction (PCR) method. All three drugs had in vitro activity against EBV in both the laboratory standard producer cell line P3HR1 and in subject-derived lymphoblastoid cell lines. The median 50\% inhibitory concentrations $\left(\mathrm{IC}_{50} \mathrm{~s}\right)$ in P3HR1 cells were: ACV, $3.4 \mu \mathrm{M}$; GCV, $2.6 \mu \mathrm{M}$; and $\mathrm{H} 2 \mathrm{G}, 2.7 \mu \mathrm{M}$ and in 3 subject-derived cells were: ACV, $2.5 \mu \mathrm{M}$; GCV, $1.7 \mu \mathrm{M}$; and $\mathrm{H} 2 \mathrm{G}, 1.9 \mu \mathrm{M}$. Our assay can be used to screen candidate anti-EBV drugs. Because we can measure the $\mathrm{IC}_{50}$ of patients' strains of EBV, this assay may also be useful for monitoring viral resistance especially in immunocompomised hosts receiving antiviral drugs for prevention or treatment of EBV diseases.
\end{abstract}

Keywords: Epstein-Barr virus, ganciclovir, acyclovir, valomaciclovir, H2G, antivirals

\section{Introduction}

Epstein-Barr virus (EBV) is associated with a wide spectrum of clinical entities ranging from asymptomatic infection to the potentially lethal post-transplant lymphoproliferative disease (PTLD). Although the use of antiviral agents in the treatment of EBV-related diseases is controversial, we have shown that valacyclovir therapy reduced oral excretion of EBV and possibly produced a clinical benefit in infectious mononucleosis. ${ }^{1}$ To assist in the selection of antiviral drugs for further clinical studies, we developed an in vitro EBV drug susceptibility assay that can be used to screen potential anti-EBV compounds. This method could also be adapted for testing patient-derived EBV strains. We evaluated acyclovir (ACV), ganciclovir (GCV) and R-9-[4-hydroxy-2-(hydroxymethyl)butyl]guanine (H2G) because these three compounds have orally bioavailable prodrugs, which make them attractive for prevention or treatment of EBV diseases in both immunocompetent and immunocompromised hosts.

\section{Materials and methods Antiviral compounds}

ACV and GCV were purchased from Sigma-Aldrich (St. Louis, MO, USA). H2G was kindly provided by Epiphany Biosciences (San Francisco, CA, USA). 


\section{Subjects}

The subjects were university students participating in a prospective study of risk factors for the acquisition and severity of primary EBV infection, which was approved by the Research Subjects Protection Program of the University of Minnesota (0608M90593). All subjects gave informed consent prior to enrollment. Subjects donated oral washes and blood samples approximately every 6 weeks. Blood samples from subjects who acquired primary EBV infections during the study were utilized for the establishment of lymphoblastoid cell lines. The subjects had not received any antiviral drugs before the samples were collected.

\section{P3HRI cells}

P3HR1 cells (ATCC HTB-62) obtained from the American Type Culture Collection, (Manassas, VA, USA) were grown in RPMI 1640 medium (Gibco ${ }^{\circledR}$; Invitrogen, Carlsbad, CA, USA) supplemented with $10 \%$ heat-inactivated fetal bovine serum ([FBS], Gemini Biologics, West Sacramento, CA, USA), $100 \mathrm{IU} / \mathrm{mL}$ penicillin and $100 \mu \mathrm{g} / \mathrm{mL}$ streptomycin (Fisher/Media Tech, Waltham MA, USA).

\section{Establishment of lymphoblastoid cell lines from subjects}

Peripheral blood samples from subjects with acute infectious mononucleosis were collected in 10-mL EDTA Vacutainer ${ }^{\circledR}$ tubes (Fisher Scientific, Houston, TX, USA). Peripheral blood mononuclear cells (PBMCs) were separated by Histopaque ${ }^{\circledR}$ 1077 (Sigma-Aldrich) density gradient centrifugation. Samples were centrifuged at $800 \times \mathrm{g}$ for 15 minutes. The layer above the frit was collected and washed twice by pelleting in phosphate buffered saline (Cellgro, MediaTech, Waltham, MA, USA), counted in a hemocytometer (American Optical, Fisher Scientific, Houston, TX, USA) and resuspended in a cryopreservative solution containing $90 \%$ FBS and 10\% dimethysulfoxide ([DMSO], Sigma-Aldrich). Samples were then frozen in aliquots of $1 \times 10^{7}$ cells at $-80^{\circ} \mathrm{C}$ before immersion in liquid nitrogen until needed for culture transformation.

Preserved PBMCs were rapidly thawed in a $37^{\circ} \mathrm{C}$ water bath, diluted to $15 \mathrm{~mL}$ in medium, washed twice and resuspended in $1 \mathrm{~mL}$ of medium containing $4 \mu \mathrm{g} / \mathrm{mL}$ of cyclosporine A ([CSA], Fluca, Sigma-Aldrich). Cells were transferred to a $25 \mathrm{~mL}$ flask and $1 \mathrm{~mL}$ of FBS was added.

Lymphoblastoid cells from subjects who had an EBV DNA viral load of $>1000$ copies $/ \mathrm{mL}$ of whole blood were incubated at $37^{\circ} \mathrm{C}$ in a humidified $5 \% \mathrm{CO}_{2}$ incubator. Transformation, seen as large floating clumps of cells, was followed by microscopic examination over a period of 4 to 8 weeks. At approximately 5-7 days and 12-14 days later, $0.5 \mathrm{~mL}$ of FBS and $0.5 \mathrm{~mL}$ of medium containing $4 \mu \mathrm{g} / \mathrm{mL}$ of CSA was added to the culture. During the third week of incubation, the culture medium was replaced by centrifugation of the culture at $600 \times \mathrm{g}$ for 10 minutes and then the cells were resuspended in fresh media without CSA.

After transformation, cells were propagated and maintained in RPMI-1640 medium containing 10\% FBS and antibiotics. Aliquots of $1 \times 10^{7}$ cells were suspended in a cryopreservative solution containing $90 \%$ FBS and $10 \%$ DMSO. Cells were frozen at $-80^{\circ} \mathrm{C}$ and stored in liquid nitrogen for later use in the in vitro susceptibility assay.

\section{In vitro antiviral susceptibility assay}

Exponentially growing P3HR1 or subject-derived lymphoblastoid cells were centrifuged at $600 \times \mathrm{g}$ for 10 minutes, resuspended, and enumerated. Cells were seeded into $25 \mathrm{~mL}$ flasks $\left(1 \times 10^{6}\right.$ cells $\left./ \mathrm{mL}\right)$, followed by $20 \mathrm{ng} / \mathrm{mL}$ of $12-\mathrm{O}$ tetradecanoylphorbol-13-acetate ([TPA], Sigma-Aldrich, St. Louis, MO) to induce the production of EBV. ${ }^{2}$ The cells were then incubated with a range of 2 -fold drug concentrations determined to encompass the $\mathrm{IC}_{50}$ in preliminary experiments. The total volume with cells, TPA, drug and medium was $10 \mathrm{~mL}$. Cells were harvested on day 7 of the culture by centrifugation of the culture at $600 \times \mathrm{g}$ for 10 minutes. Cells from flasks were resuspended in $2 \mathrm{~mL}$ of phosphate buffered saline (PBS) and enumerated using trypan blue and a hemocytometer. An aliquot equal to 1 million cells was removed and DNA extracted. If the extraction could not be performed immediately, cells were frozen at $-20^{\circ} \mathrm{C}$ until extraction. Total cellular DNA was extracted from cell pellets using the Qiagen Blood Mini Kit according to the manufacturer's protocol with the following exception: DNA was eluted in $500 \mu \mathrm{L}$ of elution buffer rather than the recommended $200 \mu \mathrm{L}$.

\section{Real time PCR detection of viral DNA}

A real time quantitative in-house PCR, (polymerase chain reaction), assay was performed to assess the antiviral activity of various drugs against EBV. ${ }^{3}$ Briefly, the amplicon was a $71 \mathrm{bp}$ portion of the EBNA1 gene. The primers and probe were designed with the assistance of Primer Express ${ }^{\circledR}$ software (PEApplied Biosystems, Foster City, CA, USA). The forward primer was: 5'-GAC TGT GTG CAG CTT TGA CGA T-3'; the reverse primer was: 5'-CGG CAG CCC CTT CCA-3'; and the probe was: $5^{\prime}$-(FAM) TAG ATT TGC CTC CCT GGT TTC CAC CTA TG-(TAMRA)-3'. The $25 \mu \mathrm{L}$ PCR 
sample contained $5 \mu \mathrm{L}$ of DNA, a $1 \times$ concentration of $\mathrm{ABI}$ $\mathrm{TaqMan}^{\circledR}$ Universal PCR Master Mix (Applied Biosystems, Foster City, CA, USA), $300 \mathrm{nM}$ of the forward and reverse primers, and $400 \mathrm{nM}$ of the probe. PCR was performed in an ABI Prism ${ }^{\circledR} 7700$ oligonucleotide sequence detector. The PCR program consisted of 1 cycle at $50^{\circ} \mathrm{C}$ for 2 minutes followed by 1 cycle at $95^{\circ} \mathrm{C}$ for 10 minutes, after which 40 cycles of $95^{\circ} \mathrm{C}$ for 15 seconds followed by $60^{\circ} \mathrm{C}$ for 1 minute were carried out. For each drug, the concentration required to reduce EBV DNA in TPA-stimulated P3HR1 cells or subject-derived cells by $50 \%\left(\mathrm{IC}_{50}\right)$ was determined by at least 3 independent experiments. Each experiment was performed in duplicate or triplicate. The $\mathrm{IC}_{50} \mathrm{~s}$ were determined using KaleidaGraph data analysis software (version 4.03, Synergy Software, Brentwood, Tenn) and by visual inspection of the inhibition plots.

\section{Results}

\section{Assay optimization}

The data we initially reported for this assay were derived from cultures in $25 \mathrm{~mL}$ flasks. ${ }^{4}$ TPA was left in the flasks for the entire 7 days and the cells were not fed during that time. A high percentage of cell death was observed during the process of enumerating the cells at the time of harvest. Lower viable cell numbers sometimes resulted in unacceptable variability between replicate dilutions. In an effort to minimize cell death and maximize EBV viral production, the procedure was modified. On day 2, 20-24 hours after TPA stimulation, the cells were repelleted, washed with phosphate-buffered saline, and resuspended in $10 \mathrm{~mL}$ of fresh medium containing the same antiviral drugs but without TPA. ${ }^{5}$ On day $4,10 \mathrm{~mL}$ of medium containing the same concentrations of antiviral drugs was added to the flasks. We demonstrated enhanced viability of the P3HR1 cells when TPA was removed on day 2 as compared with TPA being in contact with the cells for all 7 days. Data from 8 separate experiments showed that the ratio of viable to nonviable cells was improved from a mean of 1.55 (median, 1.53; standard deviation [SD], \pm 0.20 ) after 7 days of TPA exposure to a mean of 8.69 (median, 8.01; $\mathrm{SD}, \pm 2.37$ ) when TPA was removed on day 2. Similarly, the ratio of viable to nonviable subject-derived lymphoblastoid cells was improved from 0.94 to 2.29 when TPA was removed on day 2 .

A 24-well plate format, rather than the $25 \mathrm{~mL}$ flasks, was investigated in an effort to reduce the time and cost of the assay. Sixteen parallel experiments were performed in 24-well plates and $25 \mathrm{~mL}$ flasks. For the plate assay, 24-well plates were seeded with $1 \times 10^{6}$ cells per well $\left(1 \times 10^{6}\right.$ cells $\left./ \mathrm{mL}\right)$.
Cells were induced with $20 \mathrm{ng} / \mathrm{mL}$ of TPA, and incubated with the same concentrations of antiviral drugs used in the flask experiments. The total volume with cells, TPA, drug and medium was $1 \mathrm{~mL}$. The TPA was removed on day 2. On day 4, $1 \mathrm{~mL}$ of medium containing the same concentrations of antiviral drugs was added to the wells. Cells were harvested on day 7 by removing a $200 \mu \mathrm{L}$ aliquot of resuspended cells and media for extraction rather than enumerating the cells for each of the drug dilutions. This decreased the time required for harvesting cultures from 3 hours to 30 minutes. Performing the cultures in 24-well plates resulted in a 10-fold reduction in the amount of supplies needed for the assay and a 4-fold reduction in the time required to perform it. Flasks and plates showed similar ratios of EBV in the cells exposed to drug versus no drug controls. The mean flask ratio was 0.21 (median, 0.12 ; $\mathrm{SD}, \pm 0.18$ ) as compared with a mean of 0.16 for the plates (median, $0.12 ; \mathrm{SD}, \pm 0.12$ ). There was no apparent difference in cytotoxicity in wells containing drug as compared with those containing no drug for any of the 3 antiviral compounds tested.

\section{$\mathrm{IC}_{50}$ values for $\mathrm{ACV}, \mathrm{GCV}$, and $\mathrm{H} 2 \mathrm{G}$}

The median inhibition curves for the candidate antiviral drugs $\mathrm{ACV}, \mathrm{GCV}$, and $\mathrm{H} 2 \mathrm{G}$ against EBV contained in P3HR1 cells or in lymphoblastoid cell lines (L32, L52, and L57) derived from 3 different subjects with infectious mononucleosis are shown in Figure 1, Panels A, B and C. For the EBV in P3HR1 cells, the median (range) of $\mathrm{IC}_{50}$ s were: $\mathrm{ACV}, 3.4 \mu \mathrm{M}$ (2.8-6.2 $\mu \mathrm{M})$; GCV, 2.6 $\mu \mathrm{M}(1.5-3.7 \mu \mathrm{M})$, and $\mathrm{H} 2 \mathrm{G}, 2.7 \mu \mathrm{M}$ $(0.8-2.9 \mu \mathrm{M})$. The median $\mathrm{IC}_{50}$ s differed among the 3 patient strains tested. For example, the EBV in L57 cells were the most susceptible to ACV ( $\mathrm{IC}_{50}$ of $1.5 \mu \mathrm{M}$ to ACV as compared with $3.1 \mu \mathrm{M}$ for EBV in L52 cells and $3.3 \mu \mathrm{M}$ for EBV in $\mathrm{L} 32$ cells). EBV in L52 cells were the most susceptible to $\mathrm{GCV}$ ( $\mathrm{IC}_{50}$ of $0.8 \mu \mathrm{M}$ to $\mathrm{GCV}$ as compared with $1.4 \mu \mathrm{M}$ for $\mathrm{EBV}$ in $\mathrm{L} 32$ cells and $2.2 \mu \mathrm{M}$ for EBV in L57 cells). Finally, EBV in L52 cells were the most susceptible to $\mathrm{H} 2 \mathrm{G}$ ( $\mathrm{IC}_{50}$ of $0.8 \mu \mathrm{M}$ to $\mathrm{H} 2 \mathrm{G}$ as compared with $1.6 \mu \mathrm{M}$ for EBV in L57 cells and $2.1 \mu \mathrm{M}$ for EBV in L32 cells). The median, mean, and standard deviation of the $\mathrm{IC}_{50} \mathrm{~s}$ for EBV in P3HR1 cells and in the 3 patient-derived lymphoblastoid cell lines are displayed in Table 1.

\section{Discussion}

Numerous studies have described the in vitro susceptibility of EBV to candidate antiviral drugs. In all instances, the EBV evaluated was in standard laboratory cell lines, most often in P3HR1 cells, clones derived from it, Raji cells superinfected 

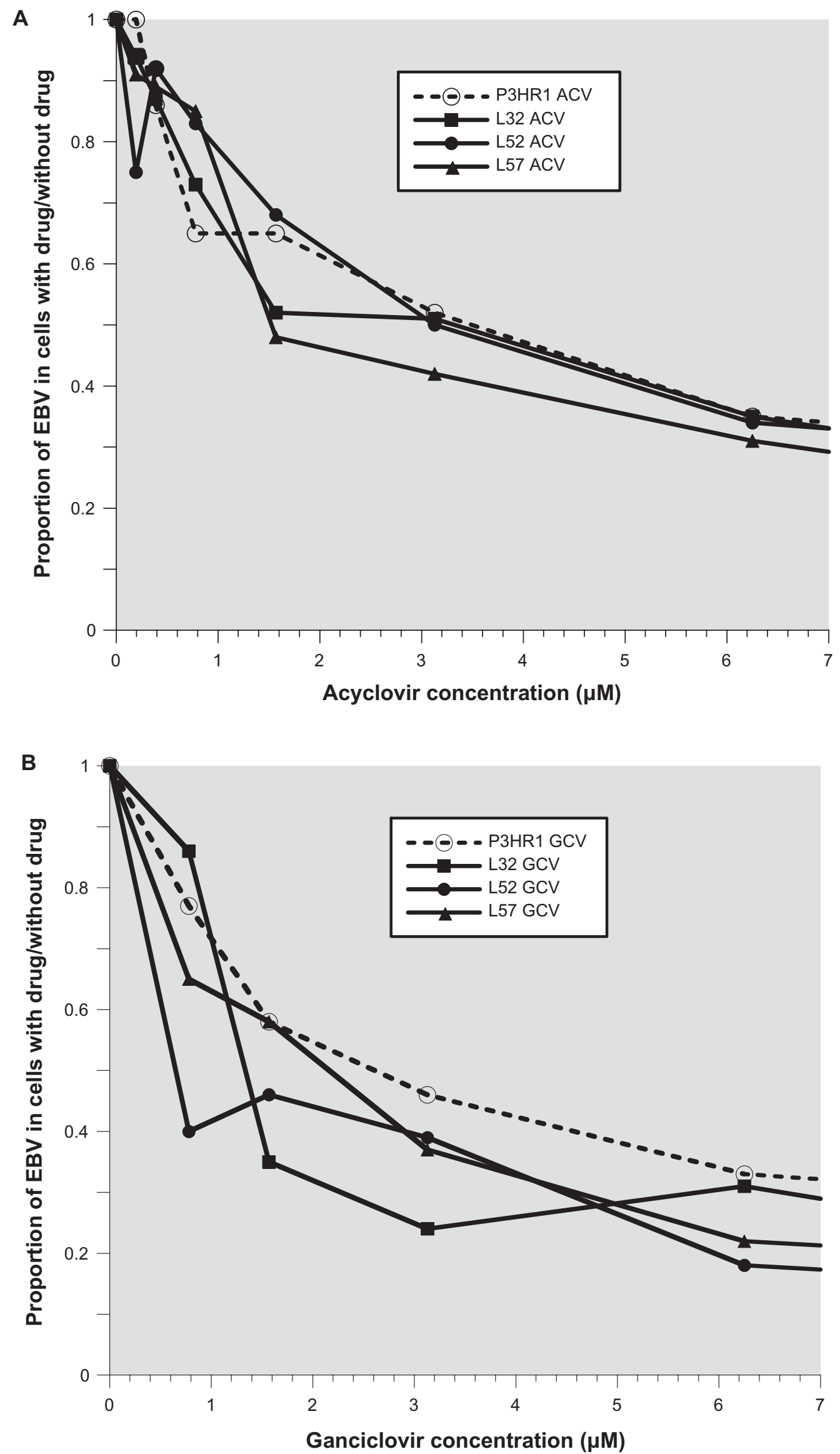


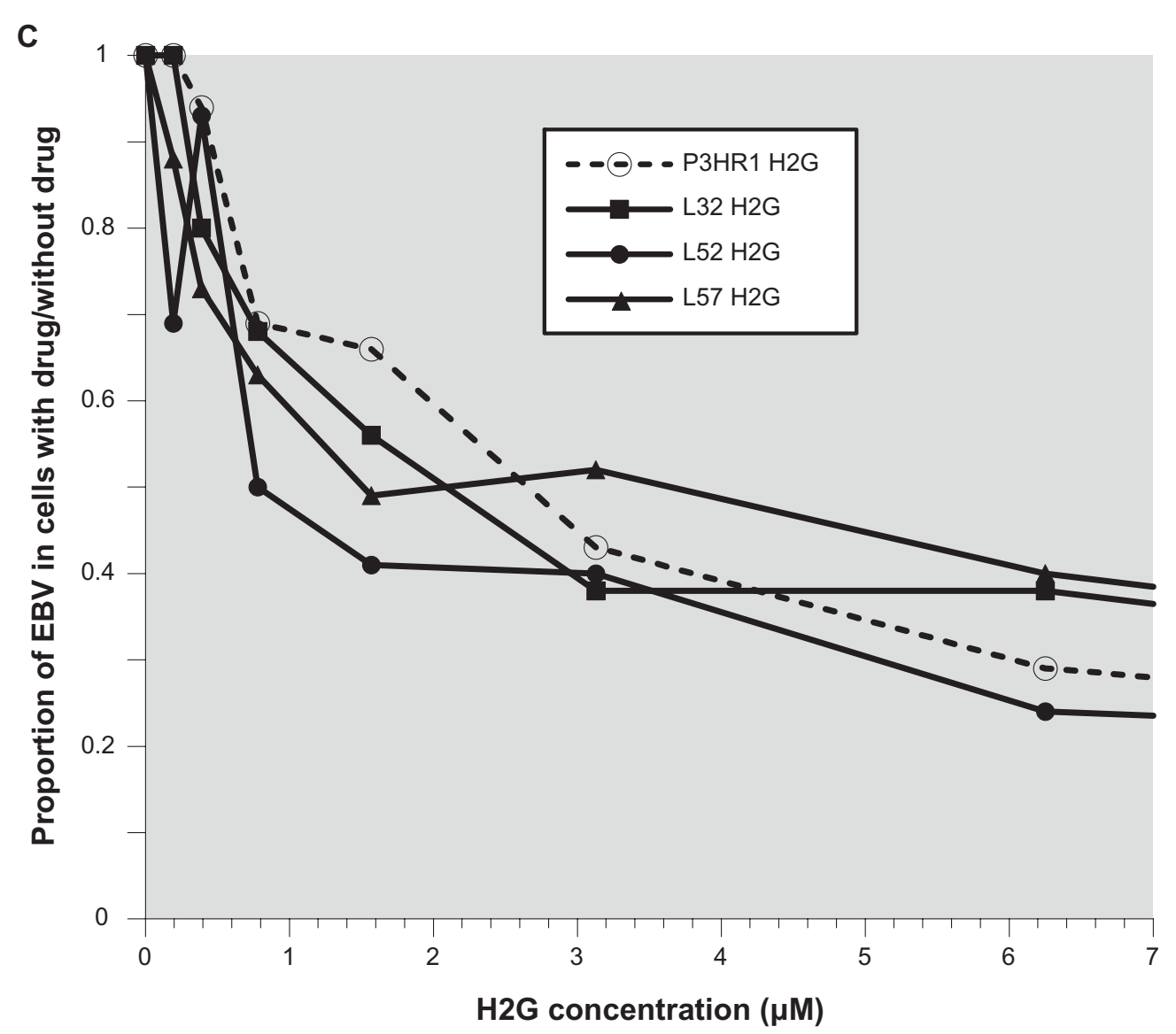

Figure I Inhibition plots of anti-EBV drug activity for acyclovir (Panel A), ganciclovir (Panel B), and H2G (Panel C). The median values obtained at each drug concentration from 52 separate experiments are shown for EBV in the producer lab cell line P3HRI and in the lymphoblastoid cell lines L32, L52 and L57 established from the peripheral blood of subjects with infectious mononucleosis.

Abbreviations: ACV, acyclovir; GCV, ganciclovir; H2G, R-9-[4-hydroxy-2-(hydroxymethyl)butyl]guanine; EBV, Epstein-Barr virus.

with P3HR1 virus, or B95-8 cells. ${ }^{6-21}$ While such information is valuable for comparing the relative effectiveness of antiviral drugs, it is a step away from assessing the actual susceptibility of patients' strains and hence cannot be used to track development of antiviral resistance. The advantage of our assay is that it can test patient-derived EBV and hence may be useful for monitoring viral resistance especially in immunocompromised hosts receiving antiviral drugs for prevention or treatment of EBV diseases.

The assays previously published are similar in that they evaluate the susceptibility of EBV in producer cell lines, most frequently P3HR1 cells. However, the procedures differ in several important ways, including the candidate antiviral drugs tested and the technique of quantifying

Table I IC ${ }_{50}^{*}(\mu \mathrm{M})$ for ACV, GCV and H2G in the EBV producer cell line P3HRI and in 3 peripheral blood lymphoblastoid cell lines of subjects with infectious mononucleosis (L32, L52 and L57)

\begin{tabular}{|c|c|c|c|c|c|c|}
\hline Antiviral drug & $I C_{50}(\mu M)$ & P3HRI & L32 & L52 & L57 & $\begin{array}{l}\text { Subject cell } \\
\text { lines L32, L52, } \\
\text { L57 combined }\end{array}$ \\
\hline \multirow[t]{2}{*}{ Acyclovir } & Median (mean) & $3.4(4.0)$ & $3.3(3.4)$ & $3.1(3.3)$ & I.5 (2.7) & $2.5(3.2)$ \\
\hline & Range & $2.8-6.2$ & I.3-5.5 & I.5-5.4 & I.4-5.6 & I.3-5.6 \\
\hline \multirow[t]{2}{*}{ Ganciclovir } & Median (mean) & $2.6(1.9)$ & $1.4(1.9)$ & $0.8(1.4)$ & $2.2(1.9)$ & $1.7(1.7)$ \\
\hline & Range & I.5-3.7 & $0.9-3.7$ & $0.8-3.1$ & I.I-2.6 & $0.8-3.7$ \\
\hline \multirow[t]{2}{*}{$\mathrm{H} 2 \mathrm{G}$} & Median (mean) & $2.7(2.3)$ & $2.1(4.5)$ & $0.8(1.8)$ & $1.6(2.4)$ & $1.9(3.0)$ \\
\hline & Range & $0.8-2.9$ & $0.8-12.0$ & $0.6-4.0$ & I.I-4.2 & $0.6-12.0$ \\
\hline
\end{tabular}

$* \mathrm{IC}_{50}$ : Concentration of drug inhibiting at least $50 \%$ of EBV DNA synthesis measured by real-time PCR. Data are from 52 separate experiments.

Abbreviations: ACV, acyclovir; GCV, ganciclovir; H2G, R-9-[4-hydroxy-2-(hydroxymethyl)butyl]guanine; EBV, Epstein-Barr virus; IC ${ }_{50}, 50 \%$ inhibitory concentrations; PVR, polymerase chain reaction. 
inhibition of EBV DNA replication. The majority of the cited studies quantified EBV replication by DNA-DNA or cRNA-DNA hybridization. In 2004, Frederichs and colleagues. ${ }^{20}$ showed that $\mathrm{IC}_{50}$ values using real-time TaqMan ${ }^{\circledR}$ PCR were similar to those generated by DNA-DNA hybridization. Because PCR is easier to perform, it is destined to replace hybridization in $\mathrm{IC}_{50}$ assays. Recently, Ballout and colleagues $^{21}$ described a real-time quantitative PCR method for assaying antiviral drug activity against EBV DNA replication and late mRNA expression. Their target DNA sequence was a portion of the EBV BXLF1 gene whereas ours was a piece of the EBNA1 gene. This could account for the difference in the $\mathrm{IC}_{50}$ for $\mathrm{GCV}$, which was the only antiviral drug we both tested. They reported an $\mathrm{IC}_{50}$ of $1.1 \mu \mathrm{M}$ \pm 0.24 (SD) to GCV in P3HR1 cells, whereas our median $\mathrm{IC}_{50}$ in P3HR1 cells was $2.6 \mu \mathrm{M}$ (range, 1.5-3.7 $\mu \mathrm{M}$ ). They also measured antiviral drug effects on EBV late mRNA expression, which was an interesting addition, although it was no more informative than DNA quantification for evaluating anti-EBV activity. However, as these authors aptly point out, the mRNA assay could prove valuable in future as more potent anti-EBV drugs with new mechanisms of action are developed.

In our assay, the anti-EBV activity of ACV, GCV, and $\mathrm{H} 2 \mathrm{G}$ was assessed in vitro using both a standard laboratory cell line (P3HR1) and lymphoblastoid cell lines from subjects with infectious mononucleosis as the source of EBV. GCV appeared to have a more clear-cut dose-response anti-EBV effect than $\mathrm{H} 2 \mathrm{G}$ or $\mathrm{ACV}$, because its $\mathrm{IC}_{50}$ slope was steeper.

Unfortunately, there is no standard formula for equating $\mathrm{IC}_{50}$ values with the clinical efficacy of an antiviral compound. The approach most often used is to strive for a plasma $\mathrm{C}_{\max }$ of the antiviral drug that is above or a certain multiple above the $\mathrm{IC}_{50}$. However, the plasma $\mathrm{C}_{\max }$ may not be the best drug exposure metric to use for this comparison. Other metrics such as the area-under-the-concentration-time curve (AUC) or the minimum post-dose concentration $\left(\mathrm{C}_{\min }\right)$ may be more clinically relevant and should be evaluated in future clinical trials. Moreover, ACV, GCV, and $\mathrm{H} 2 \mathrm{G}$ plasma concentrations do not reflect the active antiviral drug moiety. Nucleoside analogues must first be taken up by virus-infected cells and phosphorylated to their active triphosphate derivatives that inhibit viral DNA synthesis. Although intracellular nucleoside triphosphate concentrations are difficult to measure analytically, the AUCs and half-lives of these active metabolites will most likely be the in vivo pharmacokinetic metrics that best correlate with antiviral efficacy. Half-lives for ACV triphosphate and $\mathrm{H} 2 \mathrm{G}$ triphosphate in cells infected with herpes simplex virus type-1 were approximately 1 and 14 hours, respectively. ${ }^{22,23}$ The half-life of GCV triphosphate in cells infected with cytomegalovirus was approximately 12 hours. ${ }^{24}$ Half-lives for these triphosphate derivatives in EBV infected cells have not been reported, however the data described above align well with our potency findings for $\mathrm{ACV}, \mathrm{GCV}$, and $\mathrm{H} 2 \mathrm{G}$.

We previously described $\mathrm{IC}_{50}$ values of $100 \mu \mathrm{M}$ for foscarnet and $31 \mu \mathrm{M}$ for penciclovir against EBV in P3HR1 cells. ${ }^{4}$ We chose not to include these drugs in the present study because our focus was on orally bioavailable drugs with the potential to be used for prevention and treatment of EBV diseases in both immunocompetent as well as immunocompromised hosts. There is no oral formulation of foscarnet and the relatively high $\mathrm{IC}_{50}$ value for penciclovir made it problematic. We did not test cidofovir because of its unfavorable toxicity profile. Although we wanted to test maribavir we were unable to obtain it from the manufacturer.

EBV strains derived from subjects with infectious mononucleosis had slightly lower $\mathrm{IC}_{50} \mathrm{~s}$ to the antiviral drugs $\mathrm{ACV}$, GCV and $\mathrm{H} 2 \mathrm{G}$ than those found in the EBV producer laboratory cell line P3HR1. Also, there were differences in the median and mean $\mathrm{IC}_{50}$ values for EBV among the 3 subject-derived lymphoblastoid cell lines. Such differences could be informative if antiviral therapy is used, for example, in children who acquire primary EBV infection after transplantation and are at relatively high risk for post-transplant lymphoproliferative disorder (PTLD).

The viability of the producer cells was enhanced at least 5 -fold and that of the subject-derived lymphoblastoid cells at least 2-fold when TPA was left in culture for only the first day as compared with all 7 days. Adapting the assay to 24-well plates resulted in a 10 -fold reduction in the supplies required and a 4-fold reduction in technologist time required.

In conclusion, we have described $\mathrm{IC}_{50}$ values for 3 drugs that have orally bioavailable formulations and exhibit promising activity against EBV. In addition, we are reporting for the first time, to our knowledge, a method for determining drug susceptibilities of viruses from subjects with acute infectious mononucleosis. This in vitro method may be useful for monitoring development of resistance especially when immunocompromised hosts with serious EBV diseases are treated with antiviral agents.

\section{Acknowledgments}

All authors state that they have no conflicts of interest that could inappropriately influence this study. This work was supported in part by National Institutes of Health grants 
M01-RR00400 National Center for Research Resources, and 2 P01 DK13083-40A, and by the University of Minnesota International Center for Antiviral Research and Epidemiology.

\section{References}

1. Balfour HH Jr, Hokanson KM, Schacherer RM, et al. A virologic pilot study of valacyclovir for infectious mononucleosis. J Clin Virol. 2007;39(1):16-21.

2. zur Hausen H, O'Neill FJ, Freese UK, Hecker E. Persisting oncogenic herpesvirus induced by the tumour promotor TPA. Nature. 1978;272(5651):373-375.

3. Balfour HH Jr, Holman CJ, Hokanson KM, et al. A prospective clinical study of Epstein-Barr virus and host interactions during acute infectious mononucleosis. J Infect Dis. 2005;192(9):1505-1512.

4. Holman CJ, Webb CH, Romain CA, Balfour HH Jr. A method for evaluating susceptibility of EBV to antiviral drugs. Paper presented at: 47th Interscience Conference on Antimicrobial Agents and Chemotherapy 2007; Chicago, IL, USA.

5. Sergerie Y, Boivin G. Evaluation of susceptibility of human herpesvirus 8 to antiviral drugs by quantitative real-time PCR. J Clin Microbiol. 2003;41(8):3897-3900.

6. Lin JC, Smith MC, Cheng YC, Pagano JS. Epstein-Barr virus: inhibition of replication by three new drugs. Science. 1983;221(4610): $578-579$

7. Lin JC, Smith MC, Pagano JS. Prolonged inhibitory effect of 9-(1,3-dihydroxy-2-propoxymethyl)guanine against replication of Epstein-Barr virus. J Virol. 1984;50(1):50-55.

8. Lin JC, Smith MC, Pagano JS. Comparative efficacy and selectivity of some nucleoside analogs against Epstein-Barr virus. Antimicrob Agents Chemother. 1985;27(6):971-973.

9. Lin JC, Nelson DJ, Lambe CU, Choi EI. Metabolic activation of 9([2-hydroxy-1-(hydroxymethyl)ethoxy]methyl)guanine in human lymphoblastoid cell lines infected with Epstein-Barr virus. $J$ Virol. 1986;60(2):569-573.

10. Lin JC, DeClercq E, Pagano JS. Novel acyclic adenosine analogs inhibit Epstein-Barr virus replication. Antimicrob Agents Chemother. 1987;31(9):1431-1433.

11. Lin JC, Zhang ZX, Smith MC, Biron K, Pagano JS. Anti-human immunodeficiency virus agent 3'-azido-3'-deoxythymidine inhibits replication of Epstein-Barr virus. Antimicrob Agents Chemother. 1988;32(2):265-267.

12. Lin JC, Machida H. Comparison of two bromovinyl nucleoside analogs, 1-beta-D-arabinofuranosyl-E-5-(2-bromovinyl)uracil and E-5-(2-bromovinyl)-2'-deoxyuridine, with acyclovir in inhibition of Epstein-Barr virus replication. Antimicrob Agents Chemother. 1988; 32(7):1068-1072.
13. Lin JC, De Clercq E, Pagano JS. Inhibitory effects of acyclic nucleoside phosphonate analogs, including (S)-1-(3-hydroxy-2-phosphonylmethox ypropyl)cytosine, on Epstein-Barr virus replication. Antimicrob Agents Chemother. 1991;35(11):2440-2443.

14. Lin JC, Reefschlager J, Herrmann G, Pagano JS. Structure-activity relationship between (E)-5-(2-bromovinyl)- and 5-vinyl-1-beta-Darabinofuranosyluracil (BV-araU, V-araU) in inhibition of Epstein-Barr virus replication. Antiviral Res. 1992;17(1):43-52.

15. Mar EC, Chu CK, Lin JC. Some nucleoside analogs with anti-human immunodeficiency virus activity inhibit replication of Epstein-Barr virus. Antiviral Res. 1995;28(1):1-11.

16. Meerbach A, Holy A, Wutzler P, De Clercq E, Neyts J. Inhibitory effects of novel nucleoside and nucleotide analogues on Epstein-Barr virus replication. Antiviral Chemistry and Chemotherapy. 1998;9(3):275-282.

17. Meerbach A, Klocking R, Meier C, Lomp A, Helbig B, Wutzler P. Inhibitory effect of cycloSaligenyl-nucleoside monophosphates (cycloSalNMP) of acyclic nucleoside analogues on HSV-1 and EBV. Antiviral Res. 2000;45(1):69-77.

18. Kira T, Grill SP, Dutschman GE, et al. Anti-Epstein-Barr virus (EBV) activity of beta-L-5-iododioxolane uracil is dependent on EBV thymidine kinase. Antimicrob Agents Chemother. 2000;44(12):3278-3284.

19. Lin JC. Mechanism of action of glycyrrhizic acid in inhibition of Epstein-Barr virus replication in vitro. Antiviral Res. 2003; 59(1):41-47.

20. Friedrichs C, Neyts J, Gaspar G, De Clercq E, Wutzler P. Evaluation of antiviral activity against human herpesvirus 8 (HHV-8) and EpsteinBarr virus (EBV) by a quantitative real-time PCR assay. Antiviral Res. 2004;62(3):121-123.

21. Ballout M, Germi R, Fafi-Kremer S, et al. Real-time quantitative PCR for assessment of antiviral drug effects against Epstein-Barr virus replication and EBV late mRNA expression. J Virol Methods. 2007;143(1):38-44.

22. Lowe DM, Alderton WK, Ellis MR, et al. Mode of action of (R)-9[4-hydroxy-2-(hydroxymethyl)butyl]guanine against herpesviruses. Antimicrob Agents Chemother. 1995;39(8):1802-1808.

23. Furman PA, de Miranda P, St Clair MH, Elion GB. Metabolism of acyclovir in virus-infected and uninfected cells. Antimicrob Agents Chemother. 1981;20(4):518-524.

24. Biron KK, Stanat SC, Sorrell JB, et al. Metabolic activation of the nucleoside analog 9-[( 2-hydroxy-1-(hydroxymethyl)ethoxy]methyl) guanine in human diploid fibroblasts infected with human cytomegalovirus. Proc Natl Acad Sci U S A. 1985;82(8):2473-2477.
Virus Adaptation and Treatment

\section{Publish your work in this journal}

Virus Adaptation and Treatment is an international, peer-reviewed open access journal focusing on the study of virology, viral adaptation and the development and use of antiviral drugs and vaccines to achieve improved outcomes in infection control and treatment. The journal welcomes original research, basic science, clinical \& epidemiological

\section{Dovepress}

studies, reviews \& evaluations, expert opinion and commentary, case reports and extended reports. The manuscript management system is completely online and includes a very quick and fair peer-review system, which is all easy to use. Visit http://www.dovepress.com/ testimonials.php to read real quotes from published authors. 